\title{
Monitoring aminoglycoside use in patients with severely impaired renal function
}

\author{
PAUL NOONE, D F BEALE, S S POLLOCK, M R PERERA, I D AMIRAK, O N FERNANDO, \\ J F MOORHEAD
}

British Medical fournal, 1978, 2, 470-473

\section{Summary and conclusions}

Twenty patients with severely impaired renal function, 17 of whom had recently transplanted kidneys, were treated with aminoglycosides for severe infections acquired in hospital. Serum aminoglycoside concentrations were closely monitored and dosages adjusted individually to obtain peak and trough concentrations that ensured adequate treatment while avoiding toxicity. Causative organisms were susceptible to treatment in 21 out of 26 episodes of infection ( $81 \%$ ), and 12 of the 17 patients $(71 \%)$ in whom organisms were isolated were cured. Nephrotoxicity attributable to aminoglycosides alone was not observed during the 35 courses of treatment. Ototoxicity occurred in only one patient, who had excessively high serum concentrations of amikacin. Serum aminoglycoside concentrations were directly affected by carbenicillin and flucytosine. The concurrent administration of cephradine and cephalexin with gentamicin may have produced nephrotoxicity. We conclude that aminoglycosides, when carefully monitored, are effective and safe in patients with severely impaired renal function.

\section{Introduction}

Although aminoglycosides are invaluable antibiotics, especially for treating serious, hospital-acquired infections, we have insufficient data on their efficacy, ototoxicity, and nephrotoxicity in patients whose renal function is impaired owing to either chronic renal disease or recently transplanted kidneys. We report here our experience of treating 20 such patients with aminoglycosides.

\section{Patients and methods}

We studied 20 patients, of whom 14 had cadaveric renal transplants and three live-donor renal transplants. Three patients on haemodialysis had been admitted for investigation of pyrexia of unknown origin, bilateral cataract extraction, and parathyroidectomy respectively. Thirty-five courses of aminoglycoside treatment were

\footnotetext{
Microbiology and Renal Transplant Departments, Royal Free Hospital, London NW3 2QG

PAUL NOONE, BM, MRCPATH, consultant microbiologist

D F BEALE, MB, MRCP, senior registrar (present appointment: consultant physician, Bridgend General Hospital, Bridgend, Mid-Glamorgan) $S$ S POLLOCK, MB, MRCP, registrar in neurology M R PERERA, $M B$, BS, registrar

I D AMIRAK, AIMLs, senior medical laboratory scientific officer O N FERNANDO, MB, FRCs, consultant transplant surgeon J F MOORHEAD, MB, FRCP, consultant nephrologist
}

given to the 20 patients, none of whom had received aminoglycosides previously (table I). The initial dosages were readjusted as indicated by serum concentrations to achieve as far as possible the concentrations shown in table II.

Bacteriological methods-The bacteriological methods used have been described in detail elsewhere. ${ }^{1-3}$ Serum aminoglycoside concentrations were assayed by the urease method, ${ }^{4}$ which has been validated in routine use in this laboratory. ${ }^{3}$ Carbenicillin assays were performed with a standard plate-diffusion technique, using Pseudomonas aeruginosa (NCTC 10701) and Sensitest agar (Oxoid) and 18 hours' incubation. Other antibiotic assays used plate techniques and overnight incubation but with Staphylococcus aureus (NCTC 6571) as the assay organism. Flucytosine assays were performed at the Brompton Hospital microbiology department by arrangement with $\mathrm{Mr}$ Howard Wingfield.

TABLE I-Courses of antibiotics given to 20 patients, and initial doses

\begin{tabular}{|c|c|c|c|c|c|}
\hline \multirow[b]{2}{*}{ Antibiotics } & \multicolumn{4}{|c|}{ No of courses } & \multirow[b]{2}{*}{$\begin{array}{c}\text { Initial } \\
\text { dose }\end{array}$} \\
\hline & Alone & \begin{tabular}{|c|} 
In \\
combination \\
with other \\
antibiotics
\end{tabular} & Total & $\begin{array}{l}\text { Antibiotic } \\
\text { replaced }\end{array}$ & \\
\hline $\begin{array}{l}\text { Gentamicin } \\
\text { Tobramycin }\end{array}$ & $\begin{array}{r}14 \\
2\end{array}$ & $\begin{array}{r}13 \\
3\end{array}$ & $\begin{array}{r}27 \\
5\end{array}$ & Gentamicin & $\begin{array}{l}1-2 \mathrm{mg} / \mathrm{kg} \\
1-2 \mathrm{mg} / \mathrm{kg}\end{array}$ \\
\hline Sisomicin & 2 & & 2 & Gentamicin & $1 \mathrm{mg} / \mathrm{kg}$ \\
\hline Amikacin & 1 & & 1 & & $7 \mathrm{mg} / \mathrm{kg}$ \\
\hline
\end{tabular}

TABLE II-Peak and trough aminoglycoside concentrations

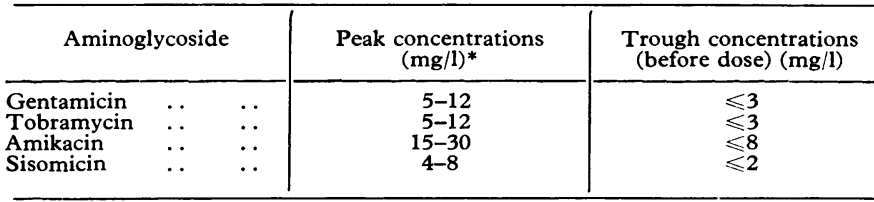

*Attained one hour after intramuscular injection and 15 minutes after intravenous injection.

Assessment of dysfunction of eighth cranial nerve-Patients receiving aminoglycosides were questioned and assessed at frequent intervals, both as inpatients and when attending outpatient clinics, for symptoms and signs of damage to the eighth cranial nerve. Full ear, nose, and throat examination was carried out when clinically indicated, using pure-tone audiograms and standard Hallpike caloric tests to assess hearing and vestibular function.

Renal function was assessed by measuring serum creatinine concentrations serially and by clearance studies with estimations of blood urea concentrations.

\section{Results*}

Dosage of aminoglycosides-Nomograms based on serum creatinine concentrations were of little value in adjusting aminoglycoside dosage (table III). The maintenance doses required varied greatly between patients and were unrelated to serum creatinine concentration, which fluctuated widely in recently transplanted patients and appeared to lag 
TABLE III-Details of doses and serum concentrations of antibiotics and serum creatinine concentrations

\begin{tabular}{|c|c|c|c|c|c|c|c|}
\hline \multirow{2}{*}{\multicolumn{3}{|c|}{$\begin{array}{c}\text { Antibiotic } \\
\text { (No of courses) }\end{array}$}} & \multirow{2}{*}{$\begin{array}{c}\text { Total dose } \\
\text { (mg/patient) }\end{array}$} & \multirow{2}{*}{$\begin{array}{l}\text { Maintenance dose } \\
(\mathrm{mg} / \mathrm{kg} / \text { day })^{*}\end{array}$} & \multicolumn{2}{|c|}{ Mean serum concentrations (range) in $\mathrm{mg} / \mathrm{l}$} & \multirow{2}{*}{$\begin{array}{l}\text { Range of serum } \\
\text { creatinine concentrations } \\
(\mu \mathrm{mol} / \mathrm{l})\end{array}$} \\
\hline & & & & & Trough & Peak & \\
\hline $\begin{array}{l}\text { Gentamicin (27) } \\
\text { Tobramycin (5) } \\
\text { Sissomicin (2) } \\
\text { Amikacin (1) }\end{array}$ & $\begin{array}{l}\cdots \\
\cdots \\
\cdots\end{array}$ & $\begin{array}{l}\ldots \\
\because \\
\cdots\end{array}$ & $\begin{array}{c}280-3280 \\
520-970 \\
180-470 \\
3500\end{array}$ & $\begin{array}{c}0.4-3 \cdot 8 \\
0.97-2 \cdot 63 \\
0.6-1 \cdot 4 \\
3.5\end{array}$ & $\begin{array}{c}2 \cdot 8(0-15 \cdot 1) \\
2 \cdot 3(0-5 \cdot 9) \\
1 \cdot 9(1 \cdot 0-6 \cdot 8) \\
10 \cdot 7(1 \cdot 0-16 \cdot 5)\end{array}$ & $\begin{array}{c}7 \cdot 4(3 \cdot 4-20 \cdot 0) \\
7 \cdot 2(7 \cdot 0-14 \cdot 0) \\
8 \cdot 8(4 \cdot 8-12 \cdot 4) \\
27 \cdot 3(14 \cdot 8-52 \cdot 0)\end{array}$ & $\begin{array}{r}97 \cdot 2-3898 \cdot 4 \\
486 \cdot 2-1714 \cdot 9 \\
176 \cdot 8-1166 \cdot 9 \\
106 \cdot 1-1635 \cdot 4\end{array}$ \\
\hline
\end{tabular}

*Individual patients showed wide variation in maintenance dose during each course.

Conversion: SI to traditional units-Creatinine: $1 \mu \mathrm{mol} / \mathrm{l} \approx 11.3 \mu \mathrm{g} / 100 \mathrm{ml}$.

TABLE IV-Numbers of episodes of infection caused by organisms (numbers of deaths in parentheses)

\begin{tabular}{|c|c|c|c|c|c|c|c|c|c|}
\hline & & Total & $\begin{array}{c}\text { Urinary tract } \\
\text { infection }\end{array}$ & $\begin{array}{c}\text { Infected } \\
\text { transplanted } \\
\text { kidney }\end{array}$ & $\begin{array}{l}\text { Wound } \\
\text { infection }\end{array}$ & $\left|\begin{array}{c}\text { Intra-abdominal } \\
\text { abscess }\end{array}\right|$ & $\begin{array}{l}\text { Peritoneal } \\
\text { infection }\end{array}$ & Pneumonia & Bacteraemia \\
\hline 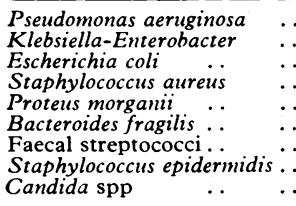 & $\begin{array}{l}\cdots \\
\cdots \\
\cdots \\
\cdots \\
\cdots \\
\cdots\end{array}$ & $\begin{array}{r}11 \\
8 \\
4 \\
3 \\
1 \\
1 \\
1 \\
1 \\
1\end{array}$ & $\begin{array}{l}5 \\
2 \\
1 \\
\\
\\
1 \\
1\end{array}$ & $\begin{array}{l}1(1) \\
1\end{array}$ & $\begin{array}{l}1 \text { (1) } \\
3 \text { (1) } \\
1\end{array}$ & $\begin{array}{l}1(1) \\
1\end{array}$ & $\begin{array}{l}1(1) \\
1 \\
2\end{array}$ & $\begin{array}{l}1 \\
3(1) \\
1 \\
1(1)\end{array}$ & $\begin{array}{ll}3 & (1) \\
1 & \\
2 & \\
1 & \end{array}$ \\
\hline
\end{tabular}

further behind current renal function than did serum aminoglycoside concentrations.

Results of treatment-Causative organisms were isolated on 26 occasions and in 17 patients (table IV). Aminoglycosides eradicated susceptible organisms in 21 episodes of infection (81\%) and cured 12 of the 17 patients $(71 \%)$. Those cured included one patient who relapsed after an initial nine-day course of treatment but responded to a further 15 days of gentamicin; one with Ps aeruginosa pneumonia who failed to respond to gentamicin but recovered when sissomicin was substituted; and one whose clinical condition improved, although pathogens persisted without other signs of sepsis. Five patients $(29 \%)$ died with sepsis as a major contributory factor despite treatment.

Multiple episodes of sepsis occurred in seven patients (table V).

Interaction in vivo between aminoglycosides and other drugs-Two patients received carbenicillin, twice with gentamicin and once with tobramycin. Serum concentrations of gentamicin on two occasions were lower than those predicted by the nomogram of Mawer et al. ${ }^{5}$ When the carbenicillin was stopped the serum aminoglycoside concentration rose in all three courses, necessitating a reduction in dosage (see fig 1). Two patients were given flucytosine for extensive candida infections at the same time as gentamicin. In one the addition of flucytosine was associated with increased trough and peak concentrations of gentamicin (fig 2), while in the other the dose of gentamicin needed to maintain adequate serum concentrations was substantially less $(3.7 \mathrm{mg} / \mathrm{kg} /$ day) than that predicted by Mawer et al's nomogram (6 $\mathrm{mg} / \mathrm{kg} /$ day). In neither patient were there changes in serum creatinine and urea concentrations. Serum concentrations of aminoglycoside were unaffected by the concurrent administration of frusemide, steroids, or azathioprine or by variations in body temperature.

Patients without proved sepsis-Six patients, five of whom had had a renal transplant, received aminoglycoside treatment although there was no conclusive laboratory evidence of bacterial infection. The treatment appeared to be clinically effective in only one patient.

Toxicity and side effects-Symptomatic evidence of ototoxicity was apparent during only one of the 35 courses of aminoglycoside treatment. The patient received gentamicin followed by amikacin, and his trough and peak serum concentrations of amikacin reached 16.5 and $50.0 \mathrm{mg} / 1$ respectively. He had bilateral loss of high-tone hearing and continuous buzzing. There was no evidence of vestibular disturbance. The symptoms have persisted unchanged for over six months. Another patient developed an unsteady gait and nystagmus one week after a course of gentamicin; but neurological examination disclosed a possible brain stem lesion, and there was no clear evidence of vestibulotoxicity or cochleotoxicity.

Renal function-No appreciable changes in renal function attributable to aminoglycoside treatment alone occurred in any of the patients. Although during gentamicin treatment serum creatinine concentrations in two patients rose by $20 \%$ and $100 \%$ and blood urea concentration in one patient rose by $30 \%$, all three patients were also suffering from transplant rejection and toxaemia, and interpretation of these results is therefore difficult. One patient receiving cephalexin and gentamicin and another receiving cephradine and gentamicin also had deteriorating renal function. Although in both cases rejection was occurring, we could not exclude nephrotoxicity.

Hepatic function remained clinically unchanged in all patients, though in one there was a reversible rise in alkaline phosphatase concentration of unknown significance.

Haemopoietic function-One patient developed a bleeding diathesis due to high serum concentrations of carbenicillin (over $2000 \mathrm{mg} / \mathrm{l}$ ), which inhibited platelet aggregation. ${ }^{6}$ No other haematological abnormalities were noted.

Central nervous system-Three patients receiving carbenicillin, penicillin, and cephradine respectively as well as gentamicin developed symptoms of mental disturbance with feelings of lethargy, drowsiness, apprehension, and impending doom, which may have been attributable
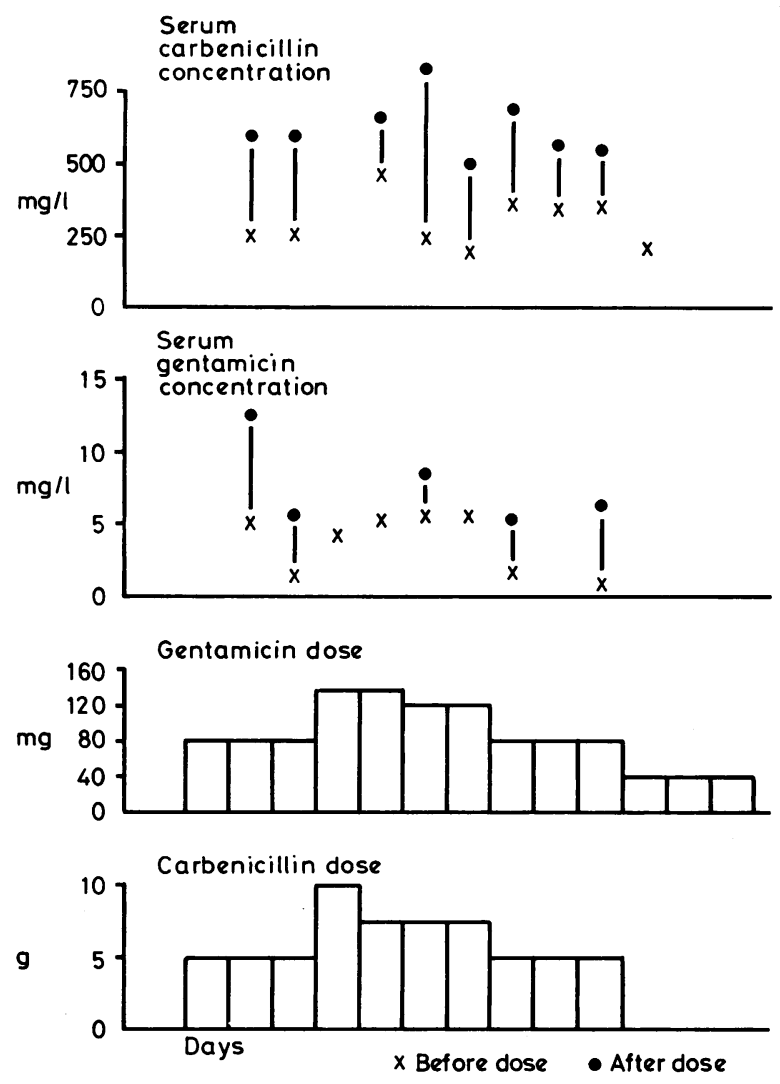

FIG 1-Serum concentrations and doses of carbenicillin and gentamicin in one patient receiving both drugs. 
TABLE v-Details of seven patients with multiple episodes of infection

\begin{tabular}{|c|c|c|c|c|c|c|}
\hline \multicolumn{3}{|c|}{ Initial infection } & \multicolumn{3}{|c|}{ Subsequent infection } & \multirow{2}{*}{$\begin{array}{l}\text { Final } \\
\text { outcome }\end{array}$} \\
\hline $\begin{array}{r}\text { Type of } \\
\text { infection }\end{array}$ & $\begin{array}{l}\text { Causative } \\
\text { organism }\end{array}$ & $\begin{array}{c}\text { Antibiotic } \\
\text { administered }\end{array}$ & $\begin{array}{c}\text { Type of } \\
\text { infection }\end{array}$ & $\begin{array}{l}\text { Causative } \\
\text { organism }\end{array}$ & $\begin{array}{c}\text { Antibiotic } \\
\text { administered }\end{array}$ & \\
\hline Pneumonia and septicaemia & Kl aerogenes* & $\begin{array}{l}\text { Gentamicin } \\
\text { (immuno- } \\
\text { suppressant } \\
\text { increased because } \\
\text { of rejection) }\end{array}$ & $\begin{array}{c}\text { Pneumonia, } 4 \text { weeks } \\
\text { later } \dagger\end{array}$ & Kl aerogenes* & Gentamicin & Responded \\
\hline Urinary tract infection & Enterobacter spp & $\begin{array}{l}\text { Gentamicin } \\
\text { Flucloxacillin } \\
\text { Co-trimoxazole }\end{array}$ & Urinary candidiasis & Candida $\mathbf{s p p}$ & Flucytosine & Successfully treated \\
\hline Pneumonia and septicaemia & Staph aureus & Gentamicin & Bilateral pneumonia & $\begin{array}{l}\text { Klebsiella } \\
\text { Pr morganii }\end{array}$ & $\begin{array}{l}\text { Gentamicin } \\
\text { Metronidazole } \\
\text { Benzylpenicillin }\end{array}$ & $\begin{array}{l}\text { Responded but died } \\
\text { later of renal } \\
\text { failure }\end{array}$ \\
\hline Wound infection & $\begin{array}{l}\text { Ecoli } \\
\text { Klebsiella } \\
\text { Faecal-type } \\
\quad \text { streptococci }\end{array}$ & & Pyrexial & Not isolated & & $\begin{array}{l}\text { Transplant } \\
\text { nephrectomy }\end{array}$ \\
\hline Septicaemia & Ps aeruginosa & $\begin{array}{l}\text { Gentamicin } \\
\text { Carbenicillin }\end{array}$ & $\begin{array}{l}\text { Deep wound } \\
\text { infection }\end{array}$ & $\begin{array}{l}\text { B fragilis } \\
\text { Kl aerogenes }\end{array}$ & $\begin{array}{l}\text { Amikacin } \\
\text { Clindamycin }\end{array}$ & Fully recovered \\
\hline $\begin{array}{l}\text { Peritonitis and } \\
\text { intra-abdominal sepsis }\end{array}$ & E coli & Gentamicin & $\begin{array}{l}\text { Subphrenic abscess, } \\
\text { septicaemia }\end{array}$ & Ps aeruginosa & Sissomicin & $\begin{array}{l}\text { Treatment } \\
\text { withdrawn. Died } \\
\text { of septicaemia }\end{array}$ \\
\hline Pneumonia & Ps aeruginosa & $\begin{array}{l}\text { Gentamicin replaced } \\
\text { by sissomicin }\end{array}$ & $\begin{array}{l}\text { Infected } \\
\text { nephrostomy and } \\
\text { site of peritoneal } \\
\text { catheter } 3 \text { weeks } \\
\text { later }\end{array}$ & Ps aeruginosa & Tobramycin & Died \\
\hline
\end{tabular}

*Same serotype.
†Clinically and radiologically distinct from first episode.

to $\beta$-lactam antibiotic neurotoxicity since all were receiving high doses and one patient had serum carbenicillin concentrations of over 2000 $\mathrm{mg} / \mathrm{l}$.

\section{Discussion}

A major hazard of renal transplant surgery is postoperative sepsis. " Immunosuppressive treatment to prevent rejection increases the risk of infection, particularly with a wide range of opportunist pathogens such as Ps aeruginosa, Klebsiella, Enterobacter, other coliforms, and fungi. This is enhanced by a long stay in hospital and treatment with broad-spectrum antibiotics. ${ }^{8}$ Because of prolonged immunosuppressive treatment infection is not confined to the postoperative period, and opportunist
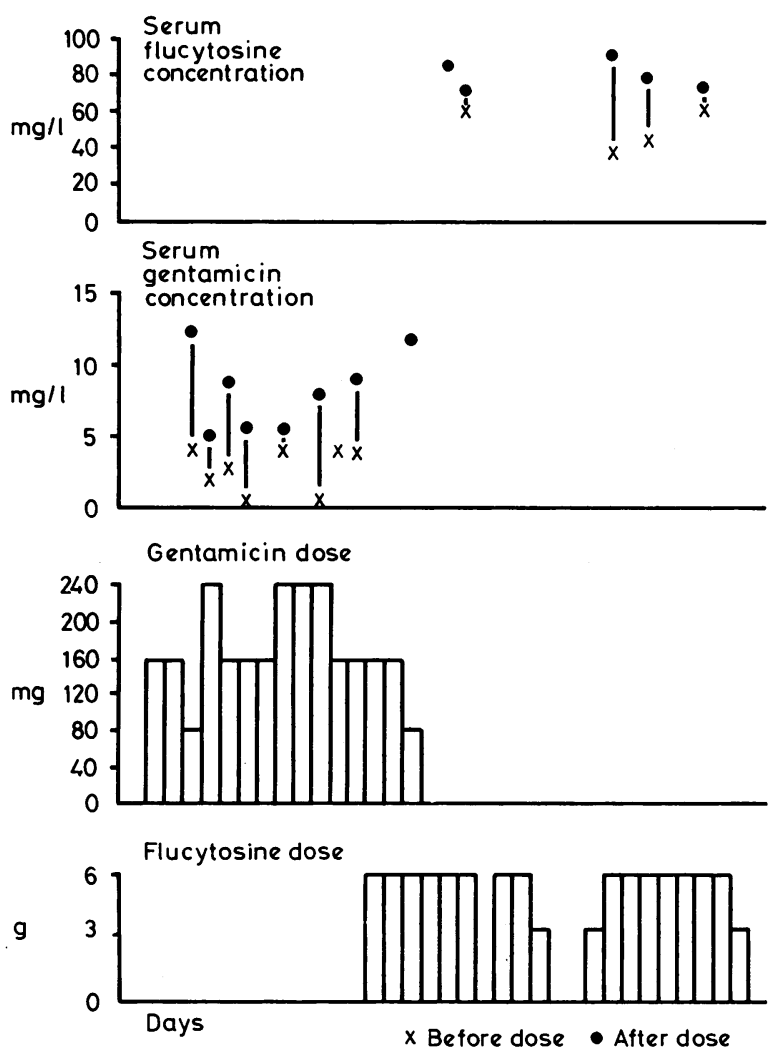

FIG 2-Serum concentrations and doses of flucytosine and gentamicin in one patient receiving both drugs. infections may develop many weeks later when granulocyte and immunoglobulin concentrations are low.

Differentiating between a rejection episode and the develop- $\vec{N}$ ment of sepsis is difficult. Because of immunosuppression $D$ major sepsis must be treated without delay, often before the results of laboratory investigation are available. The bactericidal cover of gentamicin and some of the newer aminoglycosides against a wide range of hospital coliforms, Ps aeruginosa, Staph aureus, and Staph epidermidis seems ideal from this point of view. Impaired renal function, however, demands careful monitoring of the dosage to ensure adequate treatment and avoid toxicity.

In our series of 27 episodes of proved infection 14 were immediately life threatening and five of the patients died. Apart from the Candida spp, Bacteroides fragilis, faecal-type streptococci, and one gentamicin- and tobramycin-resistant klebsiella the remaining 27 causative organisms isolated were sensitive to gentamicin, tobramycin, sissomicin, and amikacin. The patient with gentamicin-resistant klebsiella had already been successfully treated with gentamicin for $P$ s aeruginosa septicaemia. Three of the seven patients with multiple episodes of infection died, but all three had serious underlying disease and a poor prognosis.

Particular care had to be taken in giving carbenicillin and flucytosine with aminoglycosides. Carbenicillin inactivated both gentamicin and tobramycin in vivo (fig 1), necessitating an increased dose. When carbenicillin was stopped the aminoglycoside dose had to be reduced because of a rebound increase $N$ in the serum concentrations. On the other hand, flucytosine given with gentamicin led to an unexpected increase in serum gentamicin concentrations (fig 2). This could result from competition for renal excretion by the two drugs, both of which are excreted unchanged by the kidneys. ${ }^{9}$ The only combination that appeared to affect renal function adversely was an aminoglycoside with cephalosporins. This should be avoided when possible.

Nomograms were found to be of only limited value in deciding dosage for our patients. There were substantial differences in patients' requirements regardless of serum creatinine concentrations (table III). Patients with stable renal function settled on an individually tailored, consistent dose, though changes in renal function and the frequency and duration of dialysis necessitated changes in dosage (further tables and data will be supplied on request). Despite prolonged courses of aminoglycosides, sometimes in combination with other antibiotics, toxicity appeared to be low. There was no conclusive evidence of nephrotoxicity caused by aminoglycosides alone, and only one patient had definite ototoxicity. Three patients, however, showed $\beta$-lactam antibiotic toxicity. 
These findings emphasise the importance of daily close 'monitoring of peak and trough concentrations of aminoglycosides as well as concentrations before and after dialysis. A 24-hour lon-call rapid assay service allowed us to make frequent changes in dosage and timing according to the results obtained. In our experience aminoglycosides are effective and safe in this group of patients, and treatment may thus be started before infection has been bacteriologically confirmed. Immunosuppression predisposes to candida infection after renal transplantation. We did not find more patients with the infection as a result of antibiotic treatment, and only two needed treatment with flucytosine.

\section{References}

${ }^{1}$ Feathers, R S, et al, Lancet, 1977, 2, 4.

${ }^{2}$ Noone, P, and Rogers, Bogumila T, fournal of Clinical Pathology, 1976, 29, 652 .

${ }^{3}$ Noone, P, Pattison, J R, and Garfield Davies, D, Postgraduate Medical fournal, 1974, 50, suppl No 7, p 9 .

${ }^{4}$ Noone, P, Pattison, J R, and Slack, R C B, in Some Methods for Microbiological Assay, ed R J Board and D W Lovelock. New York, Academic Press, 1975.

${ }^{5}$ Mawer, G E, et al, British fournal of Pharmacology, 1974, 1, 45.

${ }^{6}$ McClure, P D, et al, Lancet, 1970, 2, 1307.

${ }^{7}$ Hall, C L, et al, British Medical fournal, 1976, 1, 547.

8 Williams, R E O, et al, Hospital Infection: Causes and Prevention, 2nd edn, pp 42 and 172. London, Lloyd-Luke, 1966.

${ }^{9}$ Wingfield, $H$, personal communication.

(Accepted 26 May 1978)

\section{SHORT REPORTS}

\section{Listeria monocytogenes causing hospital-acquired enterocolitis and meningitis in newborn infants}

Neonatal listeriosis occurs in an early form with manifestations of septicaemia and a late form with signs of meningitis. ${ }^{1-3}$ The early form is apparent within the first two days of life, the mothers being infected indicating transmission in utero. ${ }^{45}$ In the late form the mothers are healthy and the disease is probably transmitted from the environment. ${ }^{1}$ We report two outbreaks of hospital-acquired infections.

\section{Methods and patients}

Specimens were taken for isolation of Listeria monocytogenes $(\mathrm{Lm})$ from blood, CSF, faeces, and necropsy material. The methods used for the isolation and identification have been reported elsewhere. ${ }^{1}$

\section{OUTBREAK IN APRIL}

Case 1-An infant was born with congenital listeriosis of septicaemic type. She died aged 9 hours. $\mathrm{Lm}$ was cultured from the liver and the spleen at necropsy. Her mother had fever and the amniotic fluid was discoloured.

Case 2-This infant was born shortly after case 1 and at 8 days he fell ill with meningitis. His mother was healthy, and on treatment with ampicillin and sissomicin he recovered.

\section{OUTBREAK IN NOVEMBER}

Case 3-The child was ill at birth and died on the following day. $\mathrm{Lm}$ was cultured from the blood and CSF. Necropsy showed typical listeriosis of congenital type. Her mother had fever. The amniotic fluid was discoloured, and vaginal secretion gave growth of $\mathrm{Lm}$.

Cases 4 and 5-The children were born shortly after case 3 . At the age of 3 days they both fell ill with blood and slime in their stools. Their mothers were healthy. Both infants recovered on treatment with ampicillin and gentamicin.
Faeces from every child, mother, and member of the staff were cultured. Two more infections were discovered:

Case 6-The infant was born before case 3, but both were taken care of in the same room. She remained free of symptoms but culture of faeces gave growth of $\mathrm{Lm}$. Her mother was healthy.

Case 7-This boy also remained well, even though culture of both the blood and faeces gave a growth of $\mathrm{Lm}$. He was successfully treated with ampicillin. His mother was healthy.

A further 100 neonates and their mothers were investigated without finding any growth of $\mathrm{Lm}$.

\section{Comment}

Evidently case 2 with meningitis was infected by case 1, with congenital listeriosis. In the second outbreak two infants fell ill with listerial enterocolitis at the age of 3 days. Both were born shortly after the birth of an infant with congenital listeriosis. Two symptomless carriers were also found, one of whom gave a growth from both faeces and blood. One of them had been taken care of in the same room as the baby with congenital listeriosis and may have been infected there. The other carrier was born in the same department but without close contact with the other infants.

The infection may have been transmitted via the hands of the personnel or via the thermometer used for diagnosing anal atresia. Subsequently it was found that the thermometer had been used in several infants without being disinfected between consecutive cases. Precautions have been taken to prevent new outbreaks of nosocomial infection.

Address for reprints: Sture Larsson, Department of Infectious Diseases, General Hospital, S-214 01 Malmö, Sweden.

1 Larsson, S, Scandinavian Fournal of Infectious Diseases. In press.

${ }^{2}$ Larsson, S, Cronberg, S, and Winblad, S, in Proceedings of the VII International Symposium on the Problems of Listeriosis, Sept 1977. Varna, Bulgaria. In press.

${ }^{3}$ Larsson, S, Cronberg, S, and Winblad, S, Acta Paediatrica Scandinavica. Submitted for publication.

Data on two outbreaks of neonatal listeriosis

\begin{tabular}{|c|c|c|c|c|c|c|c|c|c|c|c|c|c|}
\hline $\begin{array}{l}\text { Case } \\
\text { No }\end{array}$ & $\begin{array}{c}\text { Date } \\
\text { of } \\
\text { birth }\end{array}$ & $\begin{array}{c}\text { Time } \\
\text { of } \\
\text { birth }\end{array}$ & $\begin{array}{c}\text { Week } \\
\text { of } \\
\text { pregnancy }\end{array}$ & $\begin{array}{c}\text { Birth } \\
\text { weight } \\
(\mathrm{g})\end{array}$ & Sex & $\begin{array}{c}\text { Serotype } \\
\text { of } \\
L m\end{array}$ & $\begin{array}{c}\text { Growth } \\
\text { in } \\
\text { infant }\end{array}$ & $\begin{array}{l}\text { Growth } \\
\text { in } \\
\text { mother }\end{array}$ & $\begin{array}{c}\text { Condition } \\
\text { of } \\
\text { mother }\end{array}$ & $\underset{\text { fluid }}{\text { Amniotic }}$ & $\begin{array}{c}\text { Neonatal } \\
\text { manifestation } \\
\text { of } \\
\text { disease }\end{array}$ & $\begin{array}{l}\text { Onset } \\
\text { of } \\
\text { illness } \\
\text { (days) }\end{array}$ & Outcome \\
\hline 1 & $21 \mathrm{Apr}$ & 2235 & 34 & 2250 & F & $4 B$ & $\begin{array}{l}\text { Necropsy } \\
\text { (liver, } \\
\text { spleen) }\end{array}$ & Not done & Febrile & Discol & Septicaemia & 1 & Fatal \\
\hline $\begin{array}{l}2 \\
3\end{array}$ & $\begin{array}{r}22 \mathrm{Apr} \\
7 \mathrm{Nov}\end{array}$ & $\begin{array}{l}0244 \\
1053\end{array}$ & $\begin{array}{l}41 \\
36\end{array}$ & $\begin{array}{l}3730 \\
2490\end{array}$ & $\stackrel{\mathbf{M}}{\mathbf{F}}$ & $\begin{array}{l}\text { 4B } \\
\mathbf{4 B}\end{array}$ & $\begin{array}{l}\text { CSF } \\
\text { Blood, }\end{array}$ & $\overline{+}$ & $\begin{array}{l}\text { Healthy } \\
\text { Febrile }\end{array}$ & $\begin{array}{l}\text { Normal } \\
\text { Discol }\end{array}$ & $\begin{array}{l}\text { Meningitis } \\
\text { Septicaemia }\end{array}$ & $\begin{array}{l}8 \\
1\end{array}$ & $\begin{array}{l}\text { Recovery } \\
\text { Fatal }\end{array}$ \\
\hline $\begin{array}{l}4 \\
5 \\
6 \\
7\end{array}$ & $\begin{array}{r}7 \text { Nov } \\
7 \text { Nov } \\
7 \text { Nov } \\
11 \text { Nov }\end{array}$ & $\begin{array}{l}1302 \\
1523 \\
0120\end{array}$ & $\begin{array}{l}40 \\
42 \\
40 \\
39\end{array}$ & $\begin{array}{l}2970 \\
4450 \\
4100 \\
3200\end{array}$ & $\begin{array}{l}\mathbf{M} \\
\mathbf{M} \\
\mathbf{M}\end{array}$ & $\begin{array}{l}4 B \\
4 B \\
4 B \\
4 B\end{array}$ & $\begin{array}{l}\text { Faeces } \\
\text { Faeces } \\
\text { Faeces } \\
\text { Faeces, } \\
\text { blood }\end{array}$ & Not done & $\begin{array}{l}\text { Healthy } \\
\text { Healthy } \\
\text { Healthy } \\
\text { Healthy }\end{array}$ & $\begin{array}{l}\text { Normal } \\
\text { Normal } \\
\text { Normal } \\
\text { Normal }\end{array}$ & $\begin{array}{l}\text { Enterocolitis } \\
\text { Enterocolitis } \\
\text { No symptoms } \\
\text { No symptoms }\end{array}$ & $\begin{array}{l}3 \\
3\end{array}$ & $\begin{array}{l}\text { Recovery } \\
\text { Recovery } \\
\text { Recovery } \\
\text { Recovery }\end{array}$ \\
\hline
\end{tabular}

